BLOOD GROUPS AND POPULATION GENETICS

Acta genet. $1956-57 ; 6: 517$

\title{
HEREDITARY SEROLOGICAL HUMAN SERUM GROUPS
} R.

Grubb

Bacteriological Institute, University of Lund, Sweden

An account of the investigation will be published in Acta path, microbiol. Scand. 